\title{
Corela
}

Cognition, représentation, langage

$19-2 \mid 2021$

Vol. $19, \mathrm{n}^{\circ} 2$

\section{An enactive approach to fictive motion}

\section{Aurélie Barnabé}

\section{OpenEdition}

Journals

Édition électronique

URL : https://journals.openedition.org/corela/13267

DOI : $10.4000 /$ corela. 13267

ISSN : 1638-573X

Éditeur

Cercle linguistique du Centre et de l'Ouest - CerLICO

Référence électronique

Aurélie Barnabé, «An enactive approach to fictive motion », Corela [En ligne], 19-2 | 2021, mis en ligne le 01 décembre 2021, consulté le 04 janvier 2022. URL : http://journals.openedition.org/corela/13267 ; DOI : https://doi.org/10.4000/corela.13267

Ce document a été généré automatiquement le 4 janvier 2022.

\section{(c) (i) (2) (2)}

Corela - cognition, représentation, langage est mis à disposition selon les termes de la licence Creative Commons Attribution - Pas d'Utilisation Commerciale - Partage dans les Mêmes Conditions 4.0 International. 


\title{
An enactive approach to fictive motion
}

\author{
Aurélie Barnabé
}

\section{Introduction}

The linguistic realization of the path has been explored through several works (Talmy, 2000a, 2000b; Dan I. Slobin, 1996a, 2003b; Matsumoto, 1996). The present analysis examines the linguistic structuring of a path, called the "localization path": it represents a trajectory achieved through the fictive motion (FM) of an entity along a path to reveal its localization in a spatial area. This linguistic path is inspected through a corpus-based analysis based on 120 English examples (e.g. The end of the road is going up to Toronto), including the verbs come and $g 0^{1}$.

In the first part, the linguistic paradox underlying the FM instances examined will be highlighted. In FM constructions, motion is linguistically structured through verbs to refer to the immobility of entities belonging to the external environment. This phenomenon will be illustrated through mental spaces (Fauconnier and Turner, 2002) that invite language users to assign a metonymic reference to the located entity, also called the figure element ${ }^{2}$. The specificity of the elements involved in localization events, namely the figures and the grounds will be discussed.

Speakers seem to simulate motion while processing FM occurrences (Matlock, 2004). If experiencing language is grasped through vocal utterance, this process does not preclude the role of kinetic, non-verbal modalities. In the second part, the experience of perception will hence be explored, referring to the interaction between space and the speaker's body. Our analysis will be conceived through the enactive approach, according to which a human being generates its own cognitive domain through reciprocal interaction of the brain, the body, and the world (Varela et al., 1993). The various sensory processes involved in the speaker's perception of motion will be stressed, while inspecting the aspectual load of come and go through an embodiedenactive perspective. 
In the third part, the syntactic combinations typifying the FM meaning will be exhibited and classified to define a prototypical, syntactic model mirroring the interpretative grid of FM reality. Working through the languaging experience - and not the spoken utterance only - will emphasize the complexity revealed by the transcription of visual details into linguistic sequences exposing FM meaning. An enactive approach of the semantic and lexical representation of the verbs come and go will be stressed, echoing their collective meaning as well as their local, private use in the understanding of FM scenes.

\section{The fictive motion phenomenon}

\subsection{A linguistic paradox}

Various studies investigated the linguistic actualization of the path (cf. Talmy, 2000a, 2000b; Dan I. Slobin, 1996a, 2003b, 2004; Langacker, 2000; Jackendoff, 1983, 2002; Matsumoto, 1996). The "localization path" (Barnabé, 2017: 56) ${ }^{3}$ represents the fictive motion (FM) of an entity along a trajectory to reveal its localization in a spatial area (e.g. The road goes along the crest of the hill [10, fiction, 1993] $]^{4}$ ). Localization paths are involved with an implicit type of motion which can be considered as simulated motion (Matlock, 2004: 1391). Several cognitive studies focused on the FM phenomenon, mostly assessing FM verbal constructions.

According to Matlock (2004: 1397), speakers produce FM sentences when witnessing scenes involved with implied motion. In this case, they linguistically simulate movement and visual scanning in processing fictive motion:

In several experimental studies, people actually moved, imagined moving, or directed their attention to areas in a mentally construed scene. More compelling evidence for the ubiquity of mentally simulated motion is found in research that targets 'implicit motion' (Matlock, 2004: 1393).

Moving perspectives appear to guide speakers in their verbal selections when depicting FM phenomena: in constructing a model, people take a particular perspective (e.g., bird's eye view) or a subjective perspective (e.g., protagonist's viewpoint), and they imagine themselves or others moving (Tversky, 1996). Tversly's observation converges with Talmy's, when considering the entity which fictively moves in FM constructions: Though it is not specified, the fictively moving entity can often be imagined as being a person, some body part of a person, or the focus of one's attention, depending on the particular sentence (Talmy, 2000a: 136).

In FM constructions, Langacker seems to confirm that the movement is the conceptualizer's: Nothing moves objectively. It is the conceptualizer who traces along the path to compute the trajector's fixed location, but he does so only mentally, as one aspect of his construal of the scene. (Langacker, 1999: 217). The 'trajector' represents one of the two entities involved in the scenes described. Langacker contrasts it with the 'landmark' (1991: 328). Both entities are characterized in terms of prominence. Talmy evokes both items in terms of figure/ground organization (Talmy, 2000a : 100-101). In the same vein, Matsumoto contrasts the entity whose location is indicated (the "located entity") with the entity supposed to be moving (the "moving entity") (1996: 364). The figure entity has unknown spatial properties to be determined, while the ground acts as a reference item, having known properties that can identify the figure's unknowns 
(Talmy, 2000a: 315). FM constructions are assessed according to two discrepant representations that appear to disagree with respect to some single dimension, which displays opposite poles (Ibid.: 100).

In our study, fictive motion, as a less veridical representation of motion, is coupled with stationariness ${ }^{5}$, which corresponds to a more veridical representation of the scene described. In the same vein, fictive change - as a less veridical representation - can be coupled with factive statis, as a more veridical representation (Ibid.: 101). According to Talmy (Talmy, 2000a, 2000b), fictive motion allows the conceptualizer to subjectively impose a state of change on what is otherwise understood as a stationary scene. Conversely, Matlock and Matsumoto consider that utterances underlying fictive motion create no state of change, especially when speakers describe physical space (Matlock, 2004: 1394; Matsumoto, 1996). Ambivalent observations hence apply to the assessment of the linguistic FM phenomenon.

A couple of binary terms resulting from the studies aforementioned (cf. fictive/factive or veridical/non veridical, motion/stationariness) refer to some identical reality. Such lexical dichotomies might make the understanding of FM constructions unclear. In this regard, the theory of mental spaces contributes to evidencing the processes underlying FM constructions, as explored by Fauconnier and Turner (2002). The FM construction correlates with a blended space that includes the creation of a virtual path along which there is no motion (Fauconnier and Turner, 2002: 378), as illustrated by example (1):

(1) That mountain range goes from Newfoundland to Alabama. [38, news, 2010]

In this sentence, the mountain range refers to the perceivable rocky mass in the landscape from a hiker's viewpoint "in the territory". The addition of linguistic motion to a static scene highlights a paradox, since the blend presents something that is complex and false: indeed, the mountain range is not moving along a path from Newfoundland to Alabama. Such incongruity stems from the integration network (Ibid.: 377) that displays the static situation of the mountain range in one input, while revealing the more general frame of a figure moving along a path from a beginning point to an end point in a second input. The cross-space mapping connects the path to the relevant dimension of the static object. In the mountain range blend, the static mountain range is the figure element and some additional movement has been projected from the motion input into the blend, hence presenting the figure as moving along the path from Newfoundland to Alabama, as follows: 


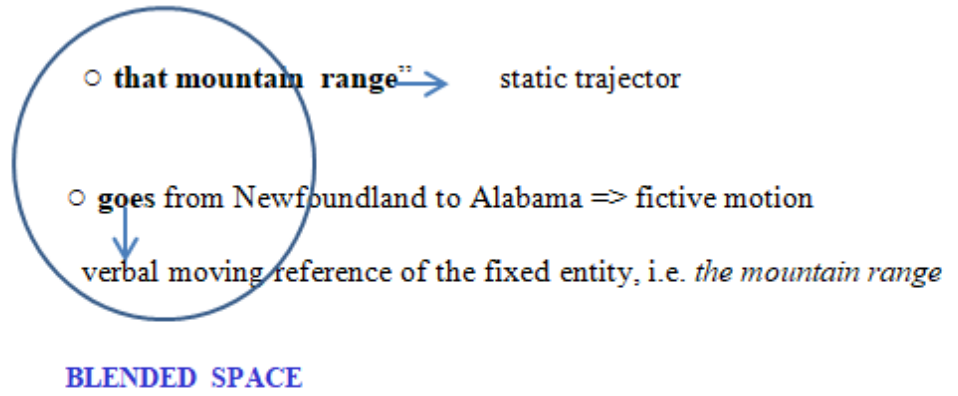

(1) That mountain range goes from Newfoundland to Alabama.

\subsection{Metonymic reading of the 'trajector'}

The blended space illustrates the linguistic paradox opposing the verbal reference to motion and the immobility of the depicted entities that can be visually observed. From a linguistic viewpoint, this paradox stems from the FM construction that assigns the figure element to the subject position combined with the movement suggested by the verb. Illustration $n^{\circ} 2$ displays the construction that uses the label for the figure in subject position. Admittedly, the mountain range moves in neither the inputs nor the blend. But because the figure element in the motion input has no counterpart in the static input, there is no label available for it in the static scene, as shown by Illustration $n^{\circ} 2$ :

Illustration $n^{\circ} 2-$ Metonymic designation of the entity 'the mountain range'

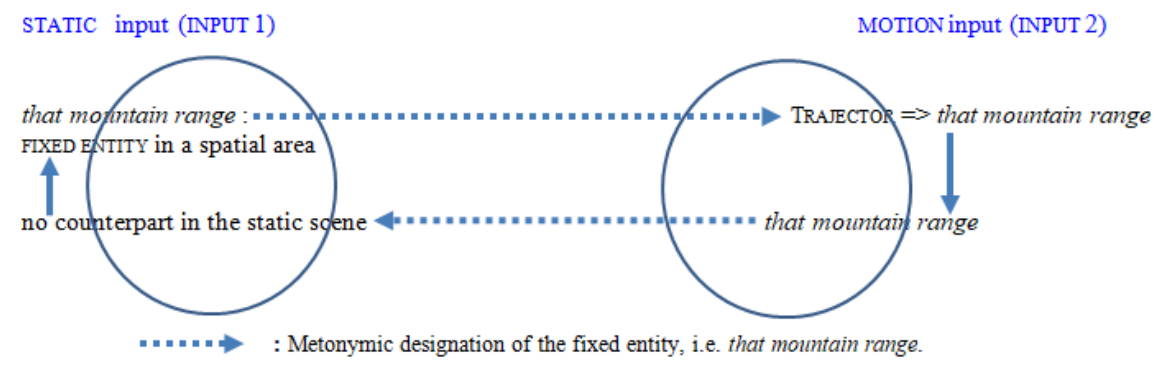

(1) That mountain range goes from Newfoundland to Alabama.

Consequently, using the label of the figure (i.e. mountain range) in subject position with a movement verb (cf. go) presents the topic that is actually talked about and it evokes the moving trajectory metonymically. What actually characterizes FM constructions is the metonymic reading of the figure. Metonymy is defined as follows: Metonymy is a cognitive process reflecting the speaker's intentions [...]. It is part of our cognitive/conceptual ability to link two related sets of entities so that the one can stand for the other in the appropriate context (Dirven et al., 2002: 80). This definition points at the dynamic reality of metonymy and its interpretative load that can be 
transferred. According to the mental spaces governing the integration network, there is a close relationship between the static input (input 1) and the dynamic input (input 2).

If the source domain (static input) and the target domain (dynamic input) belong to two different domains to reveal the mapping operation of the metaphor (Barcelona, 2002: 214), the domain highlighting replaces the domain mapping to illustrate metonymic processes: Domain highlighting consists in highlighting a secondary ${ }^{6}$ (sub)domain within the domain matrix constituted by a speaker's encyclopaedic knowledge of the meaning of a linguistic expression (Ibid.: 224). Barcelona mentions that a mapping operation actually occurs with metonymy but through some asymmetrical pattern, since metonymy includes the source/target projection within a single domain.

The static and dynamic dimensions of the source domain and the target domain actually belong to a single domain - that of velocity - which is divided into the domain displaying velocity 1 , namely stationariness, and another exhibiting velocity 2 , i.e. motion (Barnabé, 2017: 230). The metonymy characterizing FM constructions seems to correspond to the 'schematic metonymy': A schematic metonymy is a mapping of a cognitive domain, the source, onto another cognitive domain, the target, both belonging to the same overall domain, so that the source causes the mental activation of the target (Barcelona, 2002: 224).

The FM blended space is made possible by the contiguity of the mental space targeting motion and the other stressing stationariness, which gives rise to some linguistic simulation: Simulating motion is part of a fictive motion understanding (Matlock \& Richardson, 2007: 2). This process is made available by foregrounding the space targeting motion through the verb (i.e. goes), while backgrounding the space pointing at some static reality. This process is illustrated in example (1) with the mountain range in subject position: the metonymic source projects its conceptual structure onto that of the target, not by means of systematic matching of counterparts, but by conceptually foregrounding the source and by backgrounding the target (Ibid.: 226).

The intermingling of motion and stationariness within the same occurrence corresponds to the added value of conceptual integration. It highlights the emergent structure that is made possible in the blended space:

Fictive motion blends [create] a blend with emergent properties that draws on the organizing frames of both inputs. Often, the path of motion in the blend is not available to real trajectors in the real world but part of the emergent meaning in the blend is the possibility of this motion. (Fauconnier \& Turner, 2002: 380)

What precisely emerges in the blended space is the paradox occurring though linguistic items which contrast with what can be visually perceived in the external world. Surprisingly, this incongruity is collectively admitted, as speakers recurrently use motion-structured patterns to refer to static reality, as exemplified by the following integration network ${ }^{7}$ : 


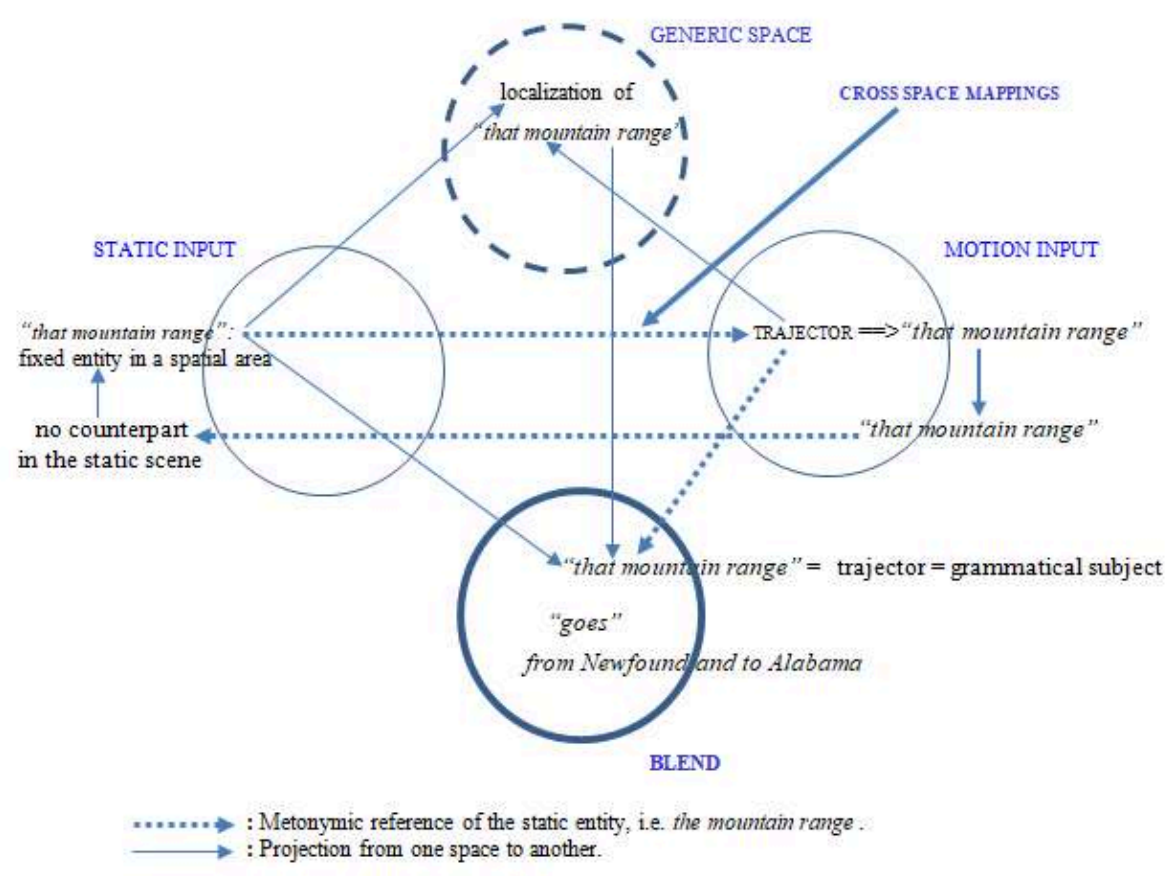

(1) That mountain range goes from Newfoundland to Alabama.

\subsection{Trajectors and landmarks}

The blended space reaches the human-scale scene of a trajectory, moving in humanscale time along a human-scale path (Ibid.: 378 ). Human-scale compatibility seems to be necessary for speakers, who paradoxically mix linguistic items referring to motion with others concurrently targeting stationariness. Human-scale compatibility is here to be understood through intentional human-scale actions speakers can project and hence structure linguistically. In our corpus-based analysis, human-scale circumstances are revealed through the semantic specificities of the 120 trajectors. Their immobility in space, their large and extended dimensions combine with come and go to disclose their static feature in space. Both verbs include the figure elements that appear in Diagram $\mathrm{n}^{\circ} 1$ among the 120 occurrences 8 : 


\section{Diagram $n^{\circ} 1-$ Figure elements}

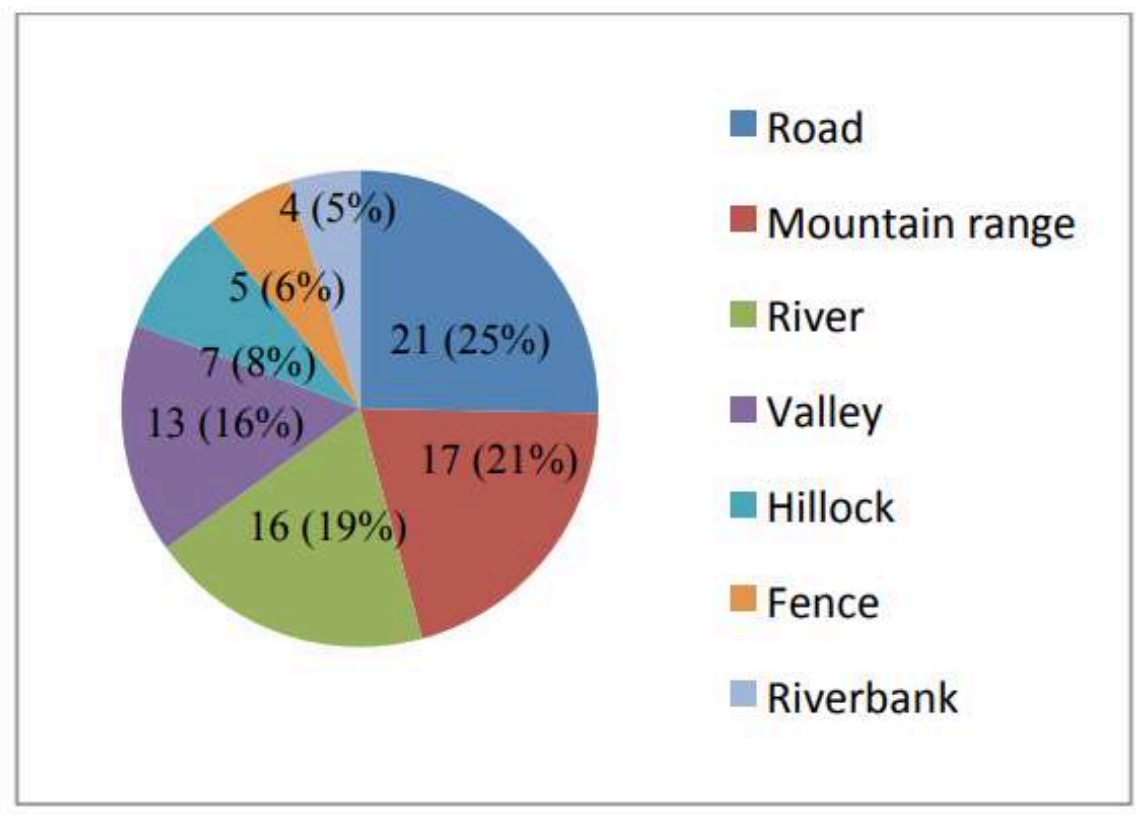

The figures displayed in Diagram $n^{\circ} 1$ represent $69 \%$ of the figure elements included with come and go. They illustrate the main items recurrently used with both verbs. All the other trajectors involved with come and go reveal analogous semantic characteristics related to their immobility and huge dimensions ${ }^{9}$. Their seemingly paradoxical semantic collocation with motion verbs seems to make sense for language users. The scarce lexical variety of the trajectors examined seems to account for the singular profile of the localization path.

In the same vein, the ground elements are seemingly characterized by some semantic unity. A difference distinguishes the grounds from the figures: each occurrence assessed exposes one trajector, while more than one landmark can appear in a single occurrence. Indeed, localization paths can include several path components in English, as a satellite-framed language ${ }^{10}$, hence displaying more than one ground:

(2) For local access, a major road comes from Bishkek via Toktogul to the ancient town. [64, FicTion, 2008]

Example (2) displays three ground elements specified through Bishkek, Toktogul and the ancient town. $11 \%$ of the data examined refer to occurrences which include more than one ground. Consequently, the quantitative assessment of the figures and the grounds reveal a superior quantity of ground elements with 145 units, compared to 120 figure elements. The lexical variety of landmarks is hence more diverse than the trajectors'. Diagram $n^{\circ} 2$ epitomizes the main lexical trends observed in the data examined and Table 1 illustrates the ground categories elaborated on the basis of the ground elements collected: 


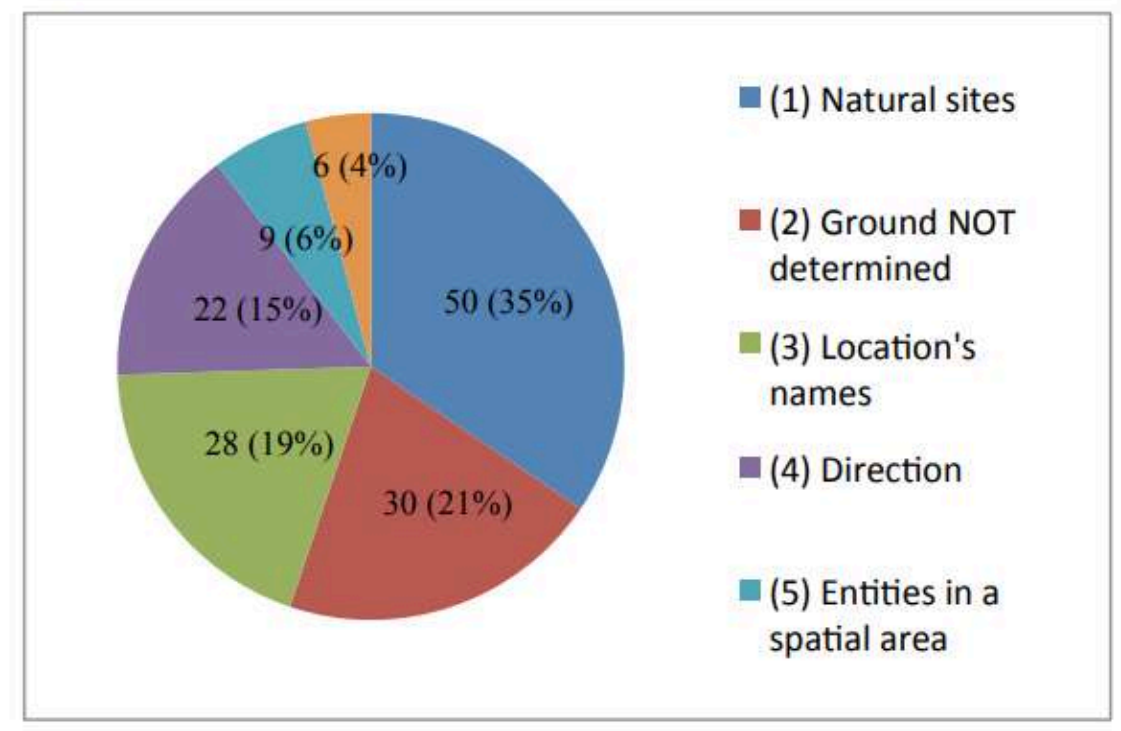

Table 1 - Ground categories

\begin{tabular}{|l|l|}
\hline \multicolumn{1}{|c|}{ GROUND CATEGORIES } & \multicolumn{1}{c|}{ EXAMPLES } \\
\hline (1) Natural sites & lake - hillside - beach - waterfall - crevice - valley - river - sea - vineyard \\
\hline (2) Ground NOT determined ${ }^{\mathrm{I1}}$ & \\
\hline (3) Location's names & Bermondse - Horry County - Carneros - New Orleans - North Carolina \\
\hline (4) Direction & the north-east - south - a complete standstill - behind - a dead-end \\
\hline (5) Entities in a spatial area & the coffin - the village - the parking - the town - the sate - the car \\
\hline (6) Numerical data & $1338 \mathrm{~m}-1200 \mathrm{~m}-3 \mathrm{~km}$ \\
\hline
\end{tabular}

In compliance with the semantic details of the figures, the grounds tend to reveal external physical elements standing as points of reference. If their lexical variety is superior to the figures', their semantic features appear to be restricted ${ }^{11}$ as well.

\subsection{Language and motion: revision of a cognitive questioning}

The studies aforementioned emphasized the relationship explored between thought about motion and language about motion. The linguistic dichotomies assessing FM and the semantic regularity of the figures and grounds involved in the localization path suggest that people simulate motion or visual scanning while processing FM occurrences. This observation challenges our theoretical devices to account for FM phenomena. Indeed, what does it mean to simulate motion? Is it mentally activating a linear path-like model based on encyclopaedic knowledge and later simulate motion along that path? Is it constructing a path-like representation and projecting some state of change on it instead of motion (Matlock, 2004)? Does motion projection only occur with words or do speakers concurrently conceptualize stationariness when linguistically producing motion?

The cognitive studies aforementioned actually evidence a couple of processes underlying the FM phenomenon at a linguistic level. And yet, many questions are left unanswered and sometimes blurred through some analyses: 
The individual "sees" the factive representation but only "senses" the fictive representation (Talmy, 2000a: 102). Models favor purely static representations (Jackendoff, 2002). Fictive motion sentences call for some kind of dynamic representation [we are underlining the text] (Matlock, Ramscar \& Boroditsky, 2003). Most observers can agree that languages systematically and extensively refer to stationary circumstances with forms and constructions whose basic reference is to motion. [...] It is more congenial for human beings to process a full, dynamic, intentional human-scale action than it is to process one apparently simple component of it (Fauconnier \& Turner, 2002: 377-379).

These comments reveal factual observations related to FM phenomena without precisely going through the internal processes giving rise to the FM verbal outcome. Accounting for the linguistic effect requires holistic considerations that do not involve language exclusively.

As mentioned earlier, thought about motion and language about motion are at stake in the FM phenomenon. Both fields of research relate to motion which always occurs in some spatial area. Movement is made possible with one's body. Therefore, space and the body are the main topics underlying the FM occurrence which is produced through speech. The interaction between speech, the body and space should be questioned to deepen the linguistic processes of FM occurrences through the process of perception. When speech is said to express one's thoughts, the stress is laid on the communicative role of voicing and writing, but nothing is said about how introverted speech [...] reflexively impresses individual thinking (Bottineau, 2010h: 76).

Instead of considering speech as a way to deliver a message, vocal utterance should be deemed as a complex multimodal process experienced by speakers. FM occurrences require visual perception and they echo what the speaker already knows about motion and stationariness. A complex process of perception hence results in the production of FM occurrences, which leads us to inquire about language through the experience it represents, not through vocal utterance only. While vocal utterance corresponds to the domain of speech, the body and space can be questioned through the kinetic, nonverbal modalities they represent in the experience of language.

\section{An enactive approach to the fictive motion processes}

\subsection{An enactive theory of perception}

If experiencing language is grasped through vocal utterance, this process does not preclude the role of head, body and eye contact. A FM occurrence results from a perceiving body which is also an experiencing body. While detecting the figure and the ground, the speaker necessarily assigns values to the regions surrounding them. Reference frames are used to specify the regions and the directionality of figures and grounds: The fact that motion is understood through perception indicates that there is a point of view which provides a reference frame for specifying the directionality (Herskovits, 1986: 25). Indeed, reference frames are fundamental in many theories of spatial relations (Svorou, 1994: 21). Grasping perceptually the world and things in space presupposes the existence of some egocentric spatial frame of reference which can be acquired through spatial relations between perceived objects and the body (Jelić et al., 2016: 486). These 
are always defined by virtue of the orientation they have to our moving bodies (Merleau-Ponty, 1945; Thompson, 2007), defined as perceiving and experiencing bodies.

From a phenomenological point of view, the body functions as "an absolute indexical "here"" (Thompson, 2007: 248) or a "degree zero of spatiality (Merleau-Ponty, 1964: 178), meaning that the space a person inhabits is constituted in regard to the referencing zero-point which is always a perceiving body. As the world is perceiverdependent, our existence can be depicted as inherently spatial - spatiality representing the sensorimotor coupling between the body and its environment. We can hence point at the co-constitution of the perceiving agent and the world, whose interplay can be inquired through the modes of embodiment of the human being as a living-lived body (Jelić et al., 2016: 5).

Among these modes of embodiment, perception may be explored in reference to the interconnection between space and the perceiving agent: which experiences of perception does the speaker go through to linguistically describe a scene whose lexical load contrasts with the visual perception of the scene implied? Our analysis is here envisaged through the enactive approach. Enaction refers to the concept that a living being is an autonomous agent that actively generates and maintains its own cognitive domain through continuous, reciprocal interaction of the brain, the body, and the world (Varela et al., 1993). Through the enactive theory of perception, the visual experience can be divided into two sub-experiences: the "passive snapshot" and the "active exploration" of the world (Jelić et al., 2016: 5). Both perspectives emphasize the embodied-enactive understanding of the agent's experience through his way of interacting with the world. The passive stance of perception refers to the reception of some load of external stimuli while perceiving actively is not something happening to us but it is something we do (Noë, 2004).

This implies that visual experience is the activity of exploring a world mediated by the knowledge of sensorimotor contingencies (O'Regan and Noë, 2001 (in Jelić et al., 2016)). In other words, sensorimotor patterns are first perceived by the individual through his sensory apparatus and through motor contingencies that differentiate sensory experiences by virtue of responding to movements [e.g. eye, head or some other bodily movements] (Jelić et al., 2016: 486). These observations echo Merleau-Ponty's theory of perception: «Ainsi, la forme de l'excitant est créée par l'organisme lui-même [...] qui choisit, dans le monde physique, les stimuli auxquels il sera sensible » (Merleau-Ponty, 1945: 236). This quote evokes a 'doubly' embodied human existence, with - on the one hand, the individual's experiencing body loaded with external stimuli's print, and - on the other hand, the perceiving subject, endowed with affective and motivational states that are intrinsic components of the of the action-perception cycle the individual is continually embedded in. This embodied-enactive approach intermingles perception, action, and emotion.

\subsection{Perception of motion through language}

Embodiment is here considered in the way the speaker apprehends lexical units through his sensorimotor dimension ${ }^{12}$ in the act of speech, echoing Bottineau's comment : «Du point de vue de l'embodiment, la parole est vécue par le parleur comme un engagement corporel improvisé et régulé, exactement comme une pratique sportive disciplinée telle que la gymnastique ou le tango » (Bottineau, 2011e: 11). In other words, 
speaking is considered in all its forms of languaging (Bottineau, 2012: 1), highlighting the perceptive stage and the mental discourse (introverted languaging) which precedes extraverted vocal languaging through speech. The aforementioned enactive theory of perception refers to languaging as a multimodal experience, apprehended by the speaker who linguistically depicts a spatial sphere perceived through his body schema:

The body schema is defined as a continuously updating neural representation of the body's configuration. [...] Body schema functions as a set of unconscious performances which combine bodily information coming from somatosensory modalities, such as proprioception and kinesthesia, into a sensory-motor schema (Cardinali et al., 2009 (in Jelić et al., 2016)).

The body schema invokes one's capacity to be aware of one's own body in the world. This concept is related to the phenomenological understanding of the lived body as a living and feeling agent: The body schema is directly involved in the pre-reflective bodily selfawareness (Merleau-Ponty, 1945). Consequently, the body schema plays a fundamental role in providing us with a consciousness of ourselves as experiencing the lived bodies (Gallagher, 2005).

If the body schema is the sensory-motor representation of the speaker's body, we may infer that the individual is also aware of his body's action possibilities, functioning as a set of dynamic sensorimotor principles that organize action and perception. This intentional action of the lived body echoes Merleau-Ponty's definition of the body schema as a "vehicle of one's bodily or motor intentionality" (Merleau-Ponty, 1945), and it mirrors Husserl's "I can" of intentional movement (Thompson, 2007). In other words, the consciousness of the agent's lived body is necessarily associated with the motor actions the agent can perform.

The enactive approach of the FM phenomenon suggests that the linguistic occurrence of motion fundamentally corresponds to the speaker's perceived movement:

The world and the organism are co-constituted because there is a viable coupling between what the world affords and our perceptual and practical capacities. On the one hand, the world informs us what we can do, while at the same time, our perceptual abilities [play a role] in perceiving and potentially engaging with what is in our world. (Ward and Stapleton, 2012 (in Jelić et al., 2016)).

This enactive understanding of perception as an anticipatory process is defined as "affordances", referring to potentialities of interaction that emerge in the agent's perception (Xenakis and Arnellos, 2013 (in Jelić et al., 2016)): Affordances are possibilities for action which are provided to an animal by its environment, including substances, surfaces, objects, and other living creatures that surround it (Gibson, 1986 (in Jelić et al., 2016)). Affordances are available by virtue of the organism's embodiment. They are determined through the speaker's language experience which is conditioned by exteroceptive information ${ }^{13}$, multisensory sensations as well as motivational, emotional and memorial states. Affordances are also patterned through abilities available in human socio-cultural practices.

These observations account for the "bias toward dynamism"14 that appear in FM occurrences (Talmy, 2000a: 171) which favor energetic, intentional human-scale action rather than stationary circumstances. The enactive theory of perception demonstrates that the "active exploration" of spatial scenes is filtered through the individual's previous knowledge of sensorimotor contingencies and it is conditioned by intentional, emotional and interoceptive states. Stillness is not privileged by speakers who select 
verbal items stressing action rather than immobility when depicting spatial scenes - a process defined as perçaction by Berthoz (Berthoz, 1997: 12):

L'art de percevoir n'est pas celui de se figurer ce qui existe : il s'agit d'extraire du chaos ambiant quelques ingrédients à partir desquels le corps concocte une synthèse hautement irréaliste et incomplète, mais hautement pragmatique et efficace orientée vers la possibilité de réagir et d'agir [...] : en discriminant des « hauts » et des «bas », des " près » et des «loins », des formes et des fonds [...], la perçaction façonne continuellement un monde modèle (et non un modèle du monde), un réel dynamique simplifié, ordonné, hiérarchisé, [propice] à l'engagement, par l'action et en vue de l'action [nous soulignons] (Bottineau, 2012: 4).

On the basis of a static scene visually perceived, the speaker uttering FM occurrences linguistically fancies the action designed by affordances that are made available by his living-lived body (Jelić et al., 2016: 486). And selecting motion verbs to depict inertness enables the individual to describe what is at stake while concurrently revealing the innate perception of his enactive and embodied condition.

\subsection{The linguistic output}

The enactive perception of motion through language can be related to the analysis of the aspectual load of come and go. The progressive ${ }^{15}$ and non-progressive ${ }^{16}$ aspects are examined, as shown by Diagram $n^{\circ} 3$ :

\section{Diagram $n^{\circ} 3$ - Aspectual load of come and go}

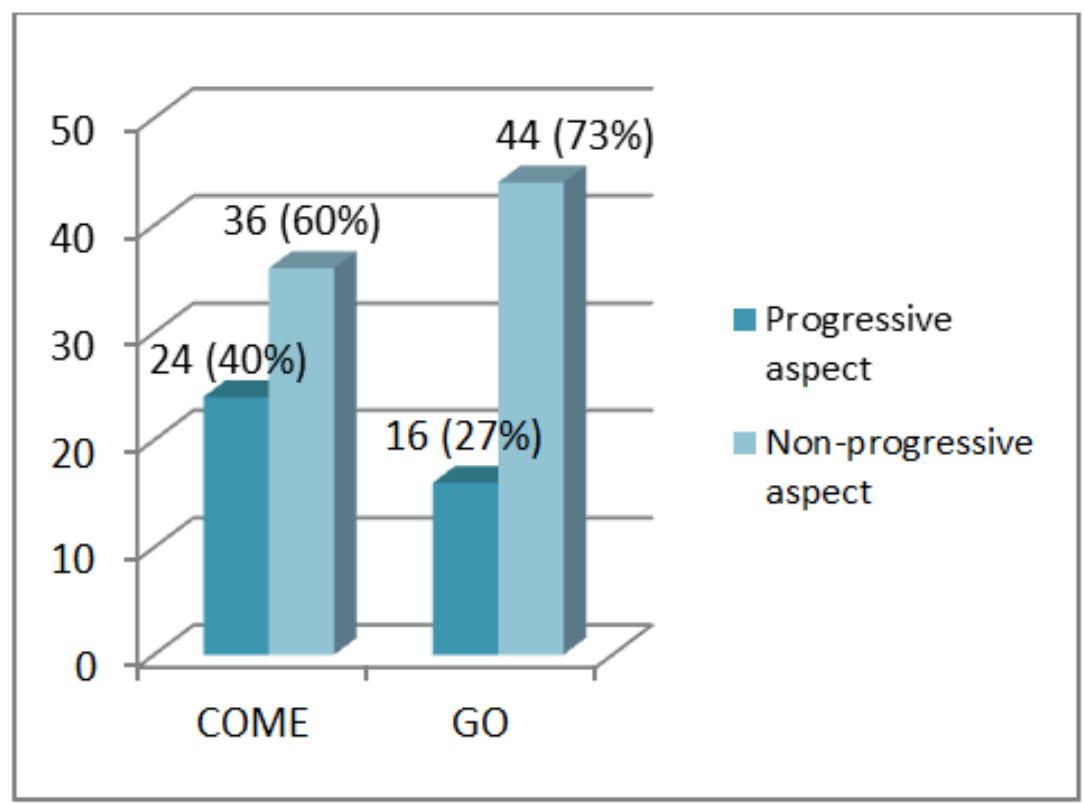

The use of the non-progressive aspect with come and go is clearly superior to the usage of the progressive: $60 \%$ examples display come and $73 \%$ occurrences include go. Both aspectual markers enable speakers to localize fixed entities:

(3) Turn left past the cow's pastures, turn right before the large white stable building, continue onto the dirt road, follow the road until the hill comes up to your left, go to the top of the hill, you will arrive at our stables! [120, NEWS, 2019] 
(4) I concentrated on the take off, but soon after we left the ground, Lyn told me to turn because the hill was coming up. [85, SPOKEN, 2010]

Example (3) is extracted from the website presentation of an Equestrian club that provides guidelines for riders who want to reach the farm to practice. The reader is given a couple of instructions, among which topographic information about the hill, which is reported to "come up": until the hill comes up to your left. As the entities described represent a landscape which does not display any change of state, the nonprogressive aspect can actually be expected: the nonprogressive [expresses] a permanent state and the progressive [expresses] a temporary state (Greenbaum \& Quirk, 1990: 56).

In comparison, example (4) depicts some identical simulated motion through the FM blend the hill was coming up, which refers to a landscape including a similar figure as the one inserted in (3), i.e. the hill. What here pertains to a temporary state does not concern the geographic information exposed in the linguistic instance. The aspectual load rather applies to the process the speaker is embedded in at the moment of the vocal utterance. In (4), Lyn and the speaker are on a plane that has just taken off; consequently, their visual perspective of the ground is progressively changing, particularly when occurrence (4) is uttered. Indeed, soon after we left the ground signals a first change of perspective (a vertical one), and Lyn told me to turn implies a second change of reference frame (a horizontal one) or a point of view which provides a reference frame for specifying the directionality (Herskovits, 1986: 25).

The hill is hence visually captured and linguistically transcribed by the speaker during this change of reference frame, which appears through the FM blend: The notion which integrates observed behavior with respect to region assignment is the notion of reference frame (Svorou, 1994: 21). The speaker reports what he visually perceives during a transitional period of time which is hence temporary. This accounts for the progressive aspect selected, i.e. was coming up. As in (4), $40 \%$ of the occurrences displaying come and $27 \%$ of the sentences including go reveal FM modes of processing that suggest sequential scanning (Langacker, 1991: 553) in which a series of component states are activated successively in non-cumulative fashion through conceived time.

This pattern recurrently exposes the living and the lived dimension of the speaker, who does not refer to the world, but rather causes an experience that happens to coincide with the narrow situation that is enacted through the vocal utterance (Bottineau, 2010h: 19). The progressive aspect hence diverts the hearer/reader's attention from the topographic frame to enact a speaker who tells more about himself than about the scene he depicts:

Le monde se présente plutôt comme un arrière-plan - un cadre, un champ qui englobe l'ensemble de notre expérience, mais qui ne se laisse pas saisir en dehors de notre structure, de notre comportement, et de notre cognition. De ce fait, ce que nous disons à propos du monde en dit au moins autant sur nous-mêmes que sur le monde (Varela et al, 1993 : 203).

In FM occurrences, the progressive aspect directly illustrates Berthoz's process of perçaction:

La perçaction ne conçoit pas la production d'une conscience visuelle du monde "perçu » comme un acte de traitement de l'information extraite de signaux de source externe, mais comme une synthèse entremêlant d'une part des processus dynamiques externes issus du monde physique à observer et dans lesquels s'engager, et d'autre part des processus dynamiques internes appartenant à la dynamique vitale continue du corps lecteur et acteur-créateur de son rapport au monde [souligné dans le texte] (Bottineau, $2014: 5$ ). 
The verbs' aspectual load represents the added value of FM occurrences, revealing proprioceptive and sensorimotor conditions of the speaker while currently disclosing external features belonging to the outward environment. Varela et al's conception of the world overlaps Berthoz's model of perçaction. Varela's foregrounding and backgrounding what is at issue matches Berthoz's inner and outer processes that portray the process of perçaction. Combined with the features qualifying fictive motion (cf. I. 1.), these binary terms echo the ambivalent structuring of reality, when perceived and lexicalized through FM utterances.

\section{When speakers enact fictive motion through simplex linguistic patterns}

\subsection{From visual perception to language: simplex processes}

FM occurrences epitomize the idea of sense-making ${ }^{17}$, echoing Fauconnier and Turner's human-scale quality of FM blends (Fauconnier and Turner, 2002: 379). Bottineau hints at the creation of a world he considers "simplifié" ${ }^{18}$, mirroring Berthoz's simplexité that indirectly refers to the enactive theory of perception:

La perception n'est pas un traitement de signal qui donnerait accès à un savoir objectif, mais la génération biologique d'un jeu vidéo simplifié et efficace, inconscient de lui-même. Cette synthèse est [créatrice] en ce qu'elle produit dans le monde physique [une mise en scène] (enaction), efficace et satisfaisante où l'humain va pouvoir naviguer et créer des connaissances indispensables à sa survie [...]. Ce processus que Berthoz qualifie de simplexe est un détour complexe qui accroît la complexité ambiante par son mode processuel mais, à l'arrivée, ergonomise le rapport du vivant au chaos ambiant qu'il convertit en terrain de jeu offert à l'engagement [souligné dans le texte] (Bottineau, $2014: 6$ ).

Berthoz's simplexité is illustrated through the paradox underlying FM phenomena that intertwine visual perception of space and its conflicting linguistic feedback:

La " simplexité » renvoie à une nécessité biologique au cours de l'évolution pour permettre la survie des animaux et de l'homme [...] : malgré la complexité des processus naturels, le cerveau doit trouver des solutions qui relèvent de principes simplificateurs. Elles permettent de traiter rapidement, avec élégance et efficacité, des situations complexes, tenant compte de l'expérience passée et anticipant l'avenir. Elles facilitent la compréhension des intentions d'autrui [...]. Elles ne sont ni des caricatures, ni des raccourcis, ni des résumés. [...] Contrairement à ce que l'on pourrait penser, simplifier n'est pas simple, car cela demande d'inhiber, de sélectionner, de lier, d'imaginer [...]. C'est ce qui se passe avec les sens. (Berthoz, 2009 : 17-18)

Visual perception is at stake in FM phenomena. Visualisation represents a phenomenological illustration portraying static items, whose linguistic, metonymic reference makes them stand in subject position. The predicate assigned to the subject calls on multisensory patterns. It is first related to sensorimotor and emotional memories, but it is also conditioned by motivational and intentional hypotheses: $L a$ vision est un processus (...) qui compose les objets perçus en leur attribuant des rôles qui impliquent le positionnement adoptable par l'observateur en termes d'action, d'émotion, de désir, de valeurs, de savoir (Bottineau, 2014 : 7).

Neurophysiology evidenced that the components coming out of a visual synthesis are mainly related to individuals' sensorimotor past experiences embedded in internal 
memory processes. On the other hand, the external features actually captured in the visual scene only represent a minor part described by the speaker (Bottineau, 2014: 67). This observation echoes Berthoz's comment on the "simplexité": chaque organisme trouve aussi des simplifications en fonction de son 'Umwelt ${ }^{19}$, c'est-à-dire de ses relations particulières avec l'environnement, en fonction de sa place au cours de l'évolution (Berthoz, 2009: 17-18).

Consequently, vision is symptomatic of connections established in the environment between entities which do not display any specific link ${ }^{20}$, and the connections created are most likely to be intertwined with the speaker, who creates his own projection of movement while depicting motion: Un organisme vivant auto-organisateur, autonome, projette sur le monde ses intentions et ses hypothèses. [...] Le privilège de l'homme est, dans une certaine mesure, de pouvoir créer des mondes (Berthoz, 2009: 27). The languaging experience is considered as a sensorimotor process that enables speakers to construct some form of mental event (Bottineau, 2010h). The languaging experience, in all its forms, cannot hence be envisaged out of the realm of bodily action, which highlights what the enactive paradigm can bring in (Ibid.: 18).

\subsection{Syntactic patterns}

On the basis of the enactive, creative process of "simplexite", one may consider that linguistic structuring of space is ordered through simplex processes. Indeed, syntactic patterns derive from the speaker's pragmatic, recollected experience when settling syntactic configurations. In this regard, he resorts to encountered processes used in past constructional patterns (Ibid.: 20). When defining the concept of simplexité, Berthoz specifies:

La simplexité anticipe plutôt qu'elle ne réagit, elle est adaptative plutôt que normative, probabiliste plutôt que déterministe. [...] Elle tient compte du temps vécu, elle part du sujet, elle permet le changement de point de vue, la création. [...] Elle impose ses lois et ses grilles d'interprétation (Berthoz, 2009 : 224).

The model of 'simplexité' echoes some of the processes underlying the interpretation grids of FM phenomena, in the sense that language users go through some creative, linguistic dimension to communicate what is to be perceived: la perception ne représente pas le X-monde par un monde stylisé, elle crée un monde (Bottineau, 2011: 27). Bottineau's quote echoes Frith's (Frith, 2007) ${ }^{21}$ : notre perception du monde est un fantasme qui coïncide avec la réalité. The gap between the linguistic represented world and external reality has to be linguistically overcome to be collectively admitted and be pragmatically efficient. The speaker hence resorts to experienced, constructional, syntactic patterns to communicate the intricate reality involved with FM scenes.

\subsubsection{Prototypical paths}

Speakers unconsciously go through complex processes (cf. perçaction, affordances) to linguistically suggest a simplex world through simplified operations (cf. simplexité). Various syntactic patterns actually structure fictive motion reality on the basis of the 120 occurrences examined. Diagram $\mathrm{n}^{\circ} 4$ illustrates the syntactic arrangements collected: 


\section{Diagram $n^{\circ} 4$ - Syntactic combinations revealing FM meaning}

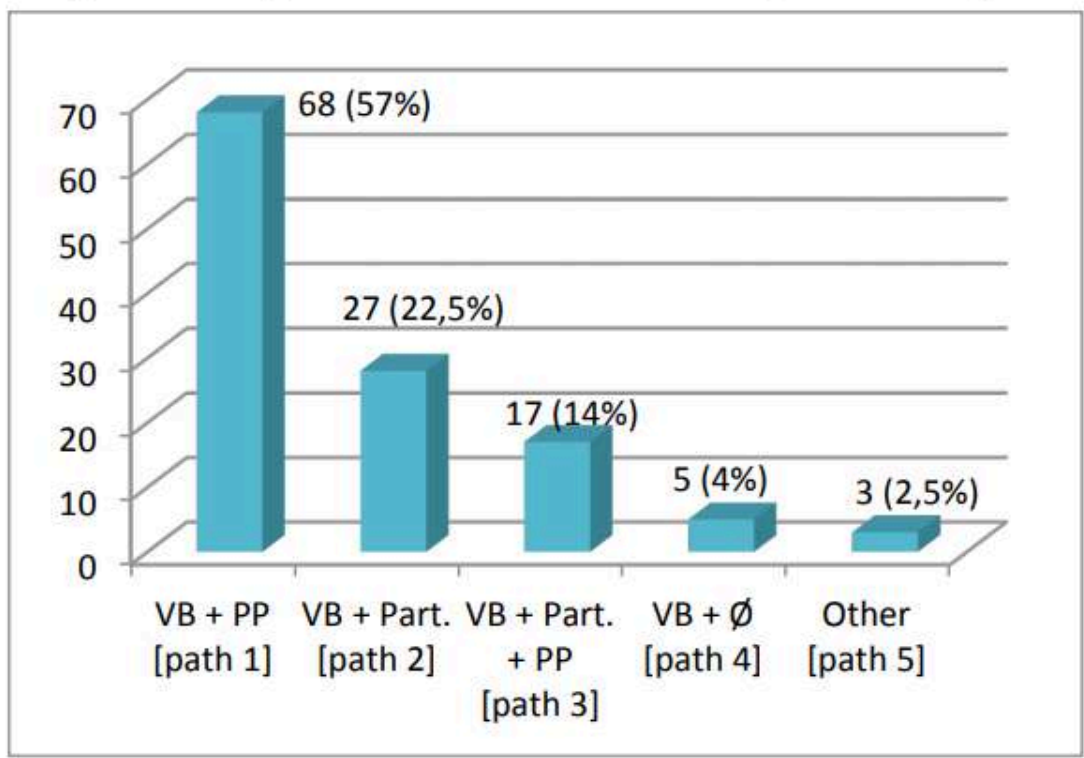

The syntactic compositions collected are dominated by [path 1]: (VB+PP) - which associates prepositional phrases ( $\mathrm{PP}$ ) with the verb (VB), as in:

(5) The mountain is coming from the North-East. [75, SPOKEN, 2010]

The verb come is linked to the PP from the North-East to structure the FM meaning. This example illustrates $57 \%$ of the occurrences assessed with come and go. In the second main syntactic arrangement, [path 2], a particle is associated to the verb (vB+Part.), as in:

(6) I hear sound/see black, I get some white flashing on my screen, the mountain range comes up, the foreground fades ... [73, FicTion, 2008]

Come is combined with the particle up to delineate some virtual itinerary with the mountain range in subject position. This syntactic pattern illustrates $22.5 \%$ of the grammatical structures observed. The third syntactic model - [path 3] - combines a prepositional phrase and a particle with the verb (VB+Part.+ PP), as in:

(7) A large meadow in front of the castle goes down to the stream. [4, FICTION, 2020]

The particle down and the preposition to specify the directionality followed by the figure, namely meadow towards the ground, i.e. the stream. On the basis of the $120 \mathrm{FM}$ instances, $14 \%$ of them are involved with this grammatical pattern. The last dominant syntactic prototype is exemplified through [path 4] which displays the verb without any closed-class units associated to it (VB ø). It represents $4 \%$ of the cases, as in:

(8) Western place comes as we sail in for our landing on the red-earth runway. [111, FICTION, 2018]

The figure Western place is the only external element specified whose outline is verbally traced by come. Some other syntactic configurations represent a minority (i.e. 2.5\%) and correspond to [path 5] (cf. Other), in which the ground element is not explicitly mentioned ${ }^{22}$.

The ground element is not necessarily specified with the five paths examined. Paths 1 and 3 include prepositional phrases that actually indicate some landmark. On the other 
hand, the ground is not mentioned when come and go are used with a particle or without any closed-class grammatical item: this is the case with path 2 ([VB+Part.]: $22.5 \%)$, path 4 ([VB+ø]: $4 \%)$, and path 5 (cf. $2.5 \%$ ), in which the ground element has to be inferred and (re)constructed on the basis of contextual information. This circumstance corresponds to $29 \%$ of the cases considered. Conversely, the ground is specified with $71 \%$ of the paths elaborated (path $1+$ path 3 ). On the basis of the data examined, speakers seem to both specify the figure and the ground elements in their recurring, syntactic output highlighting fictive motion.

\subsubsection{Complex paths}

Among the five paths examined to localize static entities, specificities pertain to the syntactic features of path 1 that combines prepositional phrases with the verb. This path can include more than one PP, as in example (9):

(9) The coastal mountain range goes from sea level to $1200 \mathrm{~m}$ within $3 \mathrm{~km}$ from the beach. There is different microclimate. [29, NEWs, 2010]

In (9), go is combined with four PP: from sea level, to $1200 \mathrm{~m}$, within $3 \mathrm{~km}$ and from the beach. This syntactic pattern conforms to the English language as a satellite-framed language ${ }^{23}$, which can encode several path segments within a single clause (Slobin, 1996a, 2003b; I. Ibarretxe-Antuñano, 2004: 328). Come and go are characterized by such uses, hence displaying several ground elements in the same clause, as in:

(10) The valley comes to a dead-end at high sheer cliffs, down which two waterfalls cascade to the ground. [79, SPOKEN, 2009]

Come is associated with three ground elements: (to) a dead-end, (at) high sheer cliffs, and (down) which two waterfalls cascade to the ground. If the use of these multi-segment paths (Slobin, 2003b) is available in English, they represent a minority in the data examined. The three combinations related to the mentioning of the ground are illustrated in Diagram $n^{\circ} 5$ :

\section{Diagram $n^{\circ} 5$ - Indication of ground elements in the clauses}

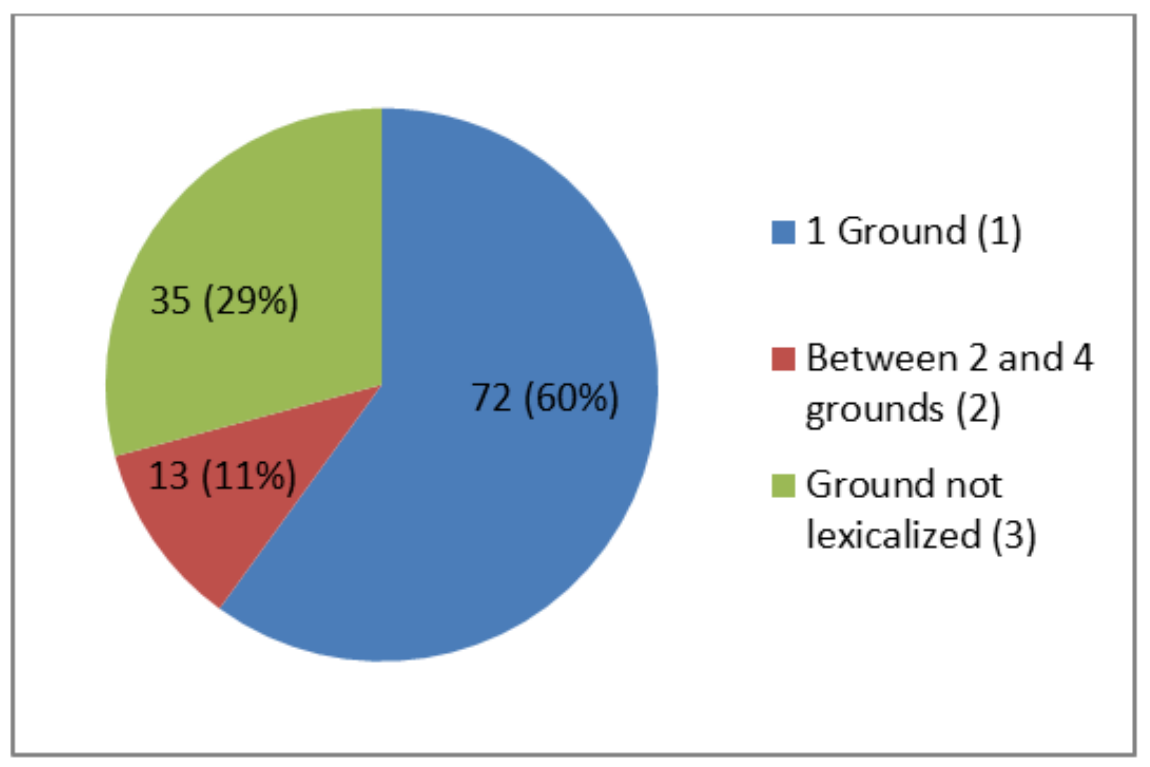


The diagram shows that ground elements either expose one [cf. (1)] or several path components [cf. (2)] within the same clause or they are not lexicalized [cf. (3)]. Among the speakers' syntactic arrangements depicting FM scenes, the explicit mentioning of one ground (cf. (1)) through PP is used in majority (i.e. 60\%), and it contrasts with a minority of instances (i.e. 11\%) which display between two and four ground elements (cf. (2)). As a whole, $71 \%$ of the occurrences (combining (1) with (2)) contrast with $29 \%$ of the examples in which the ground is not lexicalized (cf. (3)). Recurring, syntactic patterns single out the interpretative grid of FM reality, as evidenced by Illustration $n^{\circ} 4$ :

Illustration $n^{\circ} 4$ : Syntactic patterns of the localizing event

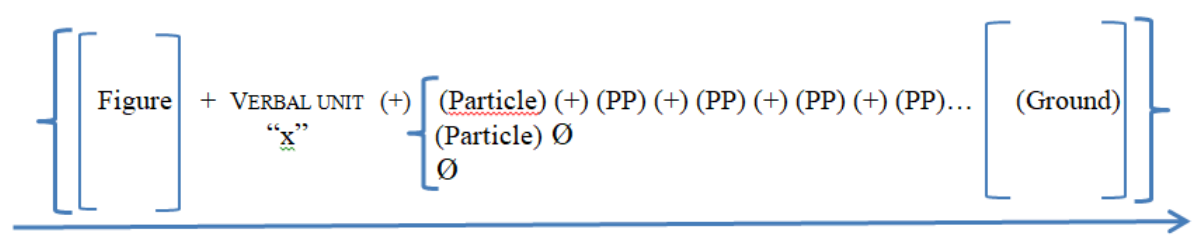

The complexity displayed by the transcription of visual details into linguistic FM sequences is here simplexified through recurrent, syntactic models. These grammatical structures are mostly solicited to represent FM meaning. In this regard, the next section questions the way verbal representation is considered through the enactive paradigm.

\subsection{Enactive approach of verbal representation}

The speaker's linguistic output pertains to his connection with the situational and pragmatic contexts, which characterize collective connections regulated by a social world (Bottineau, 2011: 29). But the way affordances are linguistically structured to reveal FM circumstances also implies that the speaker perceives a world that he enacts through simplex processes. Linguistically enacting FM scenes is actually related to the individual's personal relationships with his perception, action, emotion, and memory of the external world, echoing Berthoz's inner processes of the scheme of perçaction (Berthoz, 2009).

In this regard, the lexical load of verbs displaying FM reality echoes the speaker's private understanding of the selected verbs while concurrently mirroring his immediate and long-running experience of their use. When using come and go, speakers are guided toward both verbs' EGO centered or NON-EGO centered perspectives (Gandour, 1978) ${ }^{24}$, echoing speakers' past knowledge of them through previous, verbal encounters. In each occurrence, speakers adjust their prior insight of come and go to the immediate situation. They hence re-stage their individual experience of the verbs into the actual linguistic encounter.

The lexical background of each verb - used in purely spatial terms - maps onto imminent experience to give rise to some novel instance of come and go, as newly adapted to the simplex, syntactic structure it slips in. The verbs' reminisced, lexical load echoes some new, elaborated meaning, which reveals the speakers' past knowledge of both verbs, without directly reflecting it. And the verb selected is enacted 
as a candidate that coincides with what is at stake, hence matching with the imminent circumstances.

The verb defines an operator of recollection to federate disconnected experiences that are clustered in a network of personal, collective, private, and public instances of the verbal unit. The anterior and new, local features of the verb are organized in terms of reciprocal links and necessary conditions that appear to be activated in the impending FM depiction. The verb constitutes a symbol which is to be interpreted in its etymological root, namely a sym-bolon, as the broken fragment of some fallen object, capable of bringing back the memory of the whole object (Bottineau, 2012: 7).

On the basis of Fauconnier and Turner's mental spaces (2002), Illustration $n^{\circ} 5$ symbolizes the unconscious, cognitive operation of the lexical mapping taking place whenever go portrays FM scenes, as exemplified through (11):

(11) The Highway goes from Western British Columbia to the island of Newfoundland. [52, FICTION, 2020]

This occurrence depicts a FM scene through the past encounters of go and the immediate, linguistic situation assigning this verb. It also reflects the speaker's private understanding of go, confronted to his public knowledge of it. The 'input' of the network refers to the speaker's personal understanding of go, targeting the immediate, lexical experience of the verb, while the 'output' pertains to his public knowledge of go, turning to past encounters of the verb. And the blending space re-stages an instance of go, loaded with singular, local significance of it, echoing commonly admitted features of the verb.

Illustration $n^{\circ} 5$ - Enactive approach of verbal representation

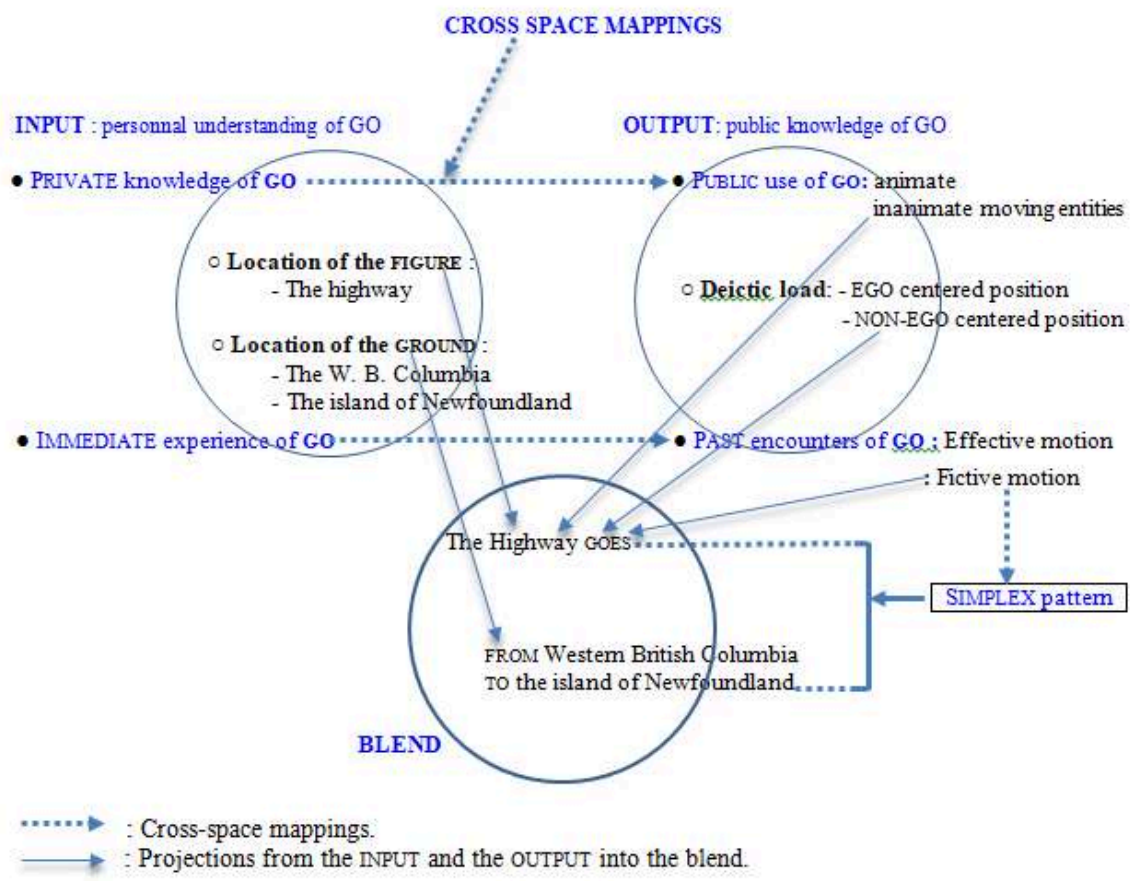

(11) The Highway goes from Western British Columbia to the island of Newfoundland.

The heterogeneous criteria elaborating a FM verbal instance suggest that the process of sense creation should be underlined in its procedural conception (Geeraerts, 2010: 260), 
and that meaning should not be considered as a reified thing that could be pictured. In (11), go does not 'represent' the FM scenario. Its 'representation' has to be interpreted in its etymological Latin root - representare, understood as "making present". The verb re-presents its past load of salience, as mapped onto some simplex pattern to make the FM scene identifiable.

Far from being the representation of a given world, FM verbal instances manifest the speaker's experimentation of a world through the operations which elaborate this experiment. This experimentation is not to be considered as a static result; it constitutes itself the process giving rise to this result (Le Moigne, 1995: 75). Representation is hence to be (re)considered as a "temporary representation", not conceived as the re-presentation of some pre-given world, but as a personal reconstruction process of extrinsic, environmental features (Varela et al., 1993: 195). The resulting FM verbal representation corresponds to a snapshot of parts of the processes the speaker is temporarily going through.

\section{Conclusion}

In the "localization path", FM processes are foregrounded through the metonymic reference of the figure. The first part attested that the paradoxical collocation of motion verbs to display the figure's immobility seems to make sense for language users through the scarce lexical variety of figures and grounds which define the singular profile of this path. Mental spaces illustrate the underlying metonymic processes of FM instances. But blended spaces only highlight FM usage-based models ${ }^{25}$. Indeed, nothing is said on the way 'thought about motion' and 'language about motion' is structured at a pre-linguistic level. In other words, the cognitive studies examining fictive motion focused on usage-based patterns, not on experience-based models. This is what the present study has brought in through the enactive approach of the "localization path", apprehended from an embodied perspective.

The viewpoint adopted in the second part has made it possible to conceptualize this path through the languaging experience. The central role of kinetic, non-verbal modalities has been stressed just as the interaction between space and the speaker's body. Assessing the aspectual load of come and go has evidenced that the living and the lived dimension of the language user does not refer to the world. It rather causes an experience that happens to coincide with the narrow situation enacted through the speaker's immediate utterance.

Interpretative, syntactic grids of FM reality have been defined in the third part. The enactive approach of such reality considers the world and the organism as coconstituted through the coupling between what the world affords and the organisms' perceptual capacities. Affordances are hence combined with the visual complexity the speaker tries to capture and convert into linguistic sequences. The speaker's proprioceptive experience and his intentional hypotheses are linguistically enacted through simplex, syntactic models, regulated by the lexical loads of come and go, which match with the impending FM scene. The resulting FM significance is superimposed on some represented meaning, which echoes speakers' and hearers' private, linguistic and kinetic knowledge. This re-presented meaning is systematically re-constructed, restaged, and re-defined through some current, linguistic construction, meant to depict some novel, contextual scene. 


\section{BIBLIOGRAPHIE}

Barcelona, A. 2002. "Clarifying and applying the notions of metaphor and metonymy within cognitive linguistics: an update”. In R. Dirven \& R. Pörings (eds.), Metaphor and Metonymy in Comparison and Contrast. Berlin/New York: Mouton de Gruyter: 207-277.

Barnabé, A. 2017. Corps, perception, déplacements: de l'expérience kinesthésique à la cognition linguistique - étude du schème du chemin en grammaire et sémantique anglaises et statut de ce schème en linguistique cognitive. Atelier national de reproduction des thèses (ANRT). I.S.B.N.: 978-2-7295-9086-4.

Berthoz, A. 2013. La Vicariance : le cerveau créateur de mondes. Paris: Odile Jacob.

Berthoz, A. 2009. La simplexité. Paris: Odile Jacob.

Berthoz, A., et I. Viaud-Delmon. 1999. Multisensory integration in spatial orientation. Current Opinion in Neurobiology, 9(6), 708-712. https://doi.org/10.1016/S0959-4388(99)00041-0

Berthoz, A. 1997. Le sens du mouvement. Paris : O. Jacob.

Bottineau, D. 2012. « Le langage représente-t-il ou transfigure-t-il le perçu ? ». La Tribune internationale des langues vivantes, Paris : Union des professeurs de langues dans les grandes écoles scientifiques, 73-82.

Bottineau, D. 2011. « Parole, corporéité, individu et société : l'embodiment entre le représentationnalisme et la cognition incarnée, distribuée et énactive dans les linguistiques cognitives ». Intellectica 56: 305-314. DOI : https://www.persee.fr/doc/ intel_0769-4113_2011_num_56_2_1152

Bottineau, D. 2010h. « Language and enaction». In J. Stewart, O. Gapenne, and E. Di Paolo (eds.), Enaction: toward a new paradigm for cognitive science, 267-306. MIT Press.

croft, W. 2009. “Toward a social cognitive linguistics”. In E. Vyvyan \& S. Pourcel (eds.), New Directions in Cognitive Linguistics. Amsterdam/Philadelphia: John Benjamins Publishing Company: 395-420.

Davies, M. 2002. Corpus of Contemporary American English (COCA). URL: https://www.englishcorpora.org/coca/

Dirven, R. \& R. Pörings. 2002. Metaphor and Metonymy in Comparison and Contrast. Berlin/New York: Mouton de Gruyter.

Fauconnier, G. \& M. Turner. 2002. The Way We Think. Conceptual Blending and the Mind's Hidden Complexities. New York: Basic Books.

Gallagher. S. 2005. How The Body Shapes The Mind. Oxford/New York: Oxford University Press. Gandour, J. 1978. "On the Deictic Use of Verbs of Motion Come and Go in Thai”. Anthropological Linguistics. Vol. 20, No. 9: 381-394. Trustees of Indiana University.

Geeraerts, D. 2010. Theories of Lexical Semantics. Oxford: Oxford University Press. Greenbaum, S. \& R. Quirk. 1990. A Student's Grammar of the English Language. London: Longman. Hampe, B. 2005. From Perception to Meaning: Image Schemas in Cognitive Linguistics. Berlin: Mouton de Gruyter. 
Herskovits, A. 1986. Language and Spatial Cognition: An Interdisciplinary Study of the Prepositions in English. Cambridge: Cambridge University Press.

Ibarretxe-Antuñano, I. 2004. "Language typologies in our language use: the case of Basque motion in adult oral narratives". Cognitive Linguistics. Volume 15 (3), 317-349.

Jackendoff, R. 2002. Foundations of Language. Oxford: Oxford University Press.

Jelić A., Tieri, G, De Matteis, F., Babiloni, F. \& G. Vecchiato. 2016. “The enactive approach to architectural experience: a neurophysiological perspective on embodiment, motivation, and affordances". Front Psychology, 7: 486. DOI: 10.3389/fpsyg.2016.00481

Langacker, R. 2000. Grammar and Conceptualization. Berlin/New York: Mouton de Gruyter.

Langacker, R. 1999. “A dynamic usage-based model”. In M. Barlow \& S. Kemmer. (ed.), Usage Based Models of Language, 1-63. Stanford, California: CSLI Publications.

Langacker, R. 1991. Foundations of Cognitive Grammar, vol. 2. Stanford: Stanford University Press. Langacker, R. 1987. Foundations of Cognitive Grammar, vol. 1. Stanford: Stanford University Press.

Le Moigne, J-L. 1995. Les Épistémologies Constructivistes. Paris : PUF.

Matlock, T. \& D. Richardson. 2007. "The integration of figurative language and static depictions: an eye movement study of fictive motion". Cognition, 102: 129-138.

Matlock, T. 2004. "Fictive motion as cognitive simulation". Teenie Matlock Stanford University Production, Number: C407. Manuscript number: 03-250s2, 1389-1400.

Matlock, T., Ramscar, M. \& L. Boroditsky. 2003. “The experiential basis of meaning”. Proceedings of the Twenty-fifth Annual Conference of the Cognitive Science Society. Mahwah, NJ: Lawrence Erlbaum.

Matsumoto, Y., Akita, K., \& K. Takahashi. 2016. "The interactionalnature of deictic verbs in English,Japanese, and Thai:Why Deixismust be treated separately from Path". In I. IbarretxeAntuñano, (ed.), Motion and Space across Languages: 95-122. John Benjamins

Matsumoto, Y. 1996. "How Abstract is Subjective Motion? A Comparison of Coverage Path Expressions and Acces Path Expressions". In A. Goldberg. Conceptual Structures, Discourse and language, 359-373. CSLI Publications.

Merleau-Ponty, M. 1964. The primacy of Perception. Evanston: Northwestern University Press.

Merleau-Ponty, M. 1945. Phénoménologie de la Perception. Paris : Éditions Gallimard.

Noë, A. 2004. Action in Perception. Cambridge: MIT Press.

Slobin, D. I. 2004. "The many ways to search for a frog: Linguistic typology and the expression of motion events”. In S. Strömqvist \& L. Verhoeven (eds.), Relating Events in Narrative: vol. 2. Typological and Contextual Perspectives, 219-257. Mahwah, N. J.: Lawrence Erlbaum Associates Publishers.

Slobin, D. I. 2003b. "Language and Thought Online: cognitive consequences of linguistic relativity". In D. Gentner \& S. Goldin-Meadow (eds), Language in Mind: Advances in the Study of Language and Thought, 157-192. Cambridge: MIT Press.

Slobin, D. I. 1996a. “From 'thought to language' to 'thinking for speaking”. In J.J. Gumperz \& Stephen C. Levinson (eds), Rethinking Linguistic Relativity, 70-96. Cambridge: Cambridge University Press.

Slobin, D. I. 1991. "Learning to think for speaking: Native language, cognition, and rhetorical style". Pragmatics 1: 7-26. 
Stapleton, M., \& T. Froese. 2016. “The enactive philosophy of embodiment: From biological foundations of agency to the phenomenology of subjectivity”. In M. García-Valdecasas, J. I. Murillo, \& N. F. Barrett (Eds.), Biology and Subjectivity: Philosophical Contributions to Nonreductive Neuroscience (Historical-Analytical Studies on Nature, Mind and Action). SpringerVerlag.

Svorou, S. 1994. The Grammar of Space. Amsterdam/Philadelphia: John Benjamins Publishing Company.

Talmy, L. 2000a. Toward a cognitive semantics: Concept Structuring Systems. Volume.1. Cambridge, Mass.: MIT Press.

Talmy, L. 2000b. Toward a cognitive semantics: Typology and Process in Concept Structuring. Volume.2. Cambridge, Mass.: MIT Press.

Thompson, E. 2007. Mind in life: biology, phenomenology, and the sciences of Mind. Cambridge: Harvard University Press.

Tversky, B. 1996. "Spatial perspectives in descriptions". In P. Bloom, M. A. Peterson, L. Nadel \& M. F. Garrett (eds.), Language and space, 463-491. Cambridge, MA: MIT Press.

Uexküll, J. von. 1909. Umwelt und Innenwelt der Tiere, Berlin, Springer: (trad. fr.) Mondes animaux et monde humain. La théorie de la signification. (1984), Paris, Denoël.

Varela, F., Thompson E., \& E. Rosch. 1993. L'Inscription Corporelle de l'Esprit. Paris : Éditions du Seuil.

\section{ANNEXES}

Annex

Annex (1) - Figure elements

Figure elements used with the verb Go :

road, mountains, valley, river, fence, mountain range, fountain, path, hotel, summit, meadow, plateau, pile, slope, highway, hillock, riverbank, cliff, wall.

Figure elements used with the verb COME :

road, mountains, valley, river, riverbank, fence, pile, mountain range, hillock, water, top of the hill, bottom of the hill, mountain top, hill, barrier, streets, terraces, edifice West Slope, province, the mining country, Western place, Valente Peak, campground, medical school, garden, bridge, garden.

Annex (2) - Ground elements classified through category (1) to category (5)

Ground elements used with the verb Go :

(1) Natural sites

the highway, the stream, uphill, the Island of Newfoundland, the valley, the bottom of the valley, the mountains, a steep illside, the edge of the area, the waterfall, the sealevel, the beach, the top, the peninsula, the end of the earth, the longest fjord in the world, the watershed, downhill, the river, the Assy River, an angle of four degrees, all points, the y-axis. 
(2) Location's names

the NY state line, Morocco, Algeria, Tunisia, Cerro de Punta, Madagascar, Newfoundland, Alabama, the city of El Paso, Western British Columbia, Athens, Lambeabe, Undurraga, Lake Mead.

(3) Direction

the left, South, North, West, horizontal, one way, all the way, northwest, east, one side, east of High Point, the South of Sunstone Knoll, the East side, its outfall, the South, nowhere, lengthwise.

(4) Entities in a spatial area

the parking, the crest, the barn, the village, the flat St. Lawrence Lowlands.

(5) Numerical data

$1200 \mathrm{~m}, 3 \mathrm{~km}, 1338$ meter,

Ground elements used with the verb COME :

(1) Natural sites

the water, a bend, the start of the Meadow Pool, the state, the rugged Canadian Shield, the Danendong ranges, Utah Lake, a small waterfall, a very deep crevice, lovely green valleys, high sheer cliffs, the Wapiti Valley, the base of Mount Democrat, a sharp point, the valley, Bhimpul Waterfall, its banks, the Missouri River, the bottom of the sea, the middle portion of a west-sloping vineyard, block, this Eastern slope.

(2) Location's names

Bishek, Toktogul, Coinjock, North Carolina, New Orleans, Carneros, Finland, Newport, Horry County, Highway 90, the cliffs, Bermondse,

(3) Direction

South, the North-East, an end, a dead-end, a complete standstill, closer, behind,

(4) Entities in a spatial area

the ancient town, the coffin, the backyard.

(5) Human entities

us

\section{NOTES}

1. The analysis clusters 60 examples including go and 60 instances inserting come, used as basic, deictic verbs in topographic depictions exclusively.

2. The basic motion event consists of one object (the Figure) moving or located with respect to another object (the reference object or Ground) [Talmy, 2000b: 25]. Figures and grounds correspond to the entities called trajectors and landmarks (Langacker, 1991, 1999) that will also be used in the present paper.

3. Through the global term "localization path", Barnabé refers to the various paths elaborated by Talmy (Talmy, 2000a: 99-175) which highlight the immobility of the figure through verbs referring to motion. 
4. The 120 occurrences are extracted from the 'Corpus of Contemporary American English' ( $\operatorname{COCA})$. Details are combined with each instance: first, the number associated to each example refers to the order occurrences are quoted. Secondly, the sources displayed by the coca are specified through NEWS and FICTION which correspond to written data, while SPOKEN refers to oral input. In final position, the year indicated concerns the year the occurrence was recorded.

5. Talmy's term stationariness is here used to refer to stationary circumstances, in reference to his theoretical assessment of fictive motion constructions (2000a: 99-175).

6. Barcelona uses the term secondary (vs. primary), already used by Croft, who refers to Langacker's terminology (Langacker, 1987: 165).

7. In the network, the 'generic (mental) space' maps onto each of the inputs and contains what the inputs have in common. (Fauconnier \& Turner, 2002: 41).

8. The data exhibit 20 entities used as trajectors with the verb go, while 28 of them are used with come. Diagram $n^{\circ} 1$ mirrors the figures that are combined with both verbs since the trajectors' lexical variety is slightly identical with come and go. Some specific work of research would actually be necessary to minutely differentiate the figures associated with each verb.

9. The 120 figure elements used with come and go are detailed in Annex (1). Diagram n¹ highlights 83 of them.

10. [In satellite-framed languages (S-languages)], narrators in real narratives need not limit a path description to a single verb and its adjuncts [...]; they may present a series of linked paths (Ibarretxe-Antuñano, 2004: 328). This observation echoes the distinction separating S-languages from verb-framed languages (V-languages) in the Talmian typology. (Talmy, 2000a, 2000b; Slobin, 1991, 2003b, 2004).

11. The lexical diversity of the grounds used with come and go are detailed in Annex (2).

12. We refer to Bottineau's remark on the ambiguous understanding of the notion of embodiment: «La linguistique cognitive (LC) a disjoint le côté L et le côté C: les actes de conceptualisation dans leur dimension non verbale sont inspirés par l'expérience sensorimotrice, et, en ce sens, "incarnés »; en revanche, les actes de parole ne sont pas envisagés dans leur dimension sensori-motrice du côté du signifiant, et sont à cet titre "désincarnés » [...] La LC se présente comme un appariement $\mathrm{L}+\mathrm{C}$ hétérogène, une linguistique désincarnée de la cognition incarnée (d'une mentalisation pure de la corporéité), un inventaire de formes (envisagés sous un angle «désincarnant») qui encodent des représentations mi-expérientielles, mi-innées.» (Bottineau, 2011e: 11).

13. Exteroceptive information refers to input being external to the body, which contrasts with interoception that includes the sense of limb position, i.e. proprioception and kinesthesia (Stapleton and Froese, 2016: 123).

14. The cognitive bias toward dynamism in language shows up not only in the fact that stationary phenomena are fictively represented in terms of motion more than the reverse. (Talmy, 2000a : 171)

15. The progressive focuses on the situation as being in progress at a particular time. In consequence, it may imply that the situation has limited duration, and that it is not necessarily complete (Greenbaum \& Quirk, 1990: 53).

16. The progressive implies temporariness whereas the nonprogressive implies permanence (Greenbaum \& Quirk, 1990: 54). As a short quantity of occurrences is examined, the aspectual form have+-en has deliberately not been worked through to favor the comparison between the progressive and the nonprogressive.

17. Sense-making echoes the values generated from within the system as a result of its relation to those parts of the world it interacts with, i.e. its "Umwelt" according to Uexküll's terminology (cf. Uexküll, J., 1909). [...] A theory of bodily sense-making is as much a theory of emotion as it is a theory of cognition (Stapleton and Froese, 2016: 121). 
18. «La perçaction façonne continuellement un monde modèle (et non un modèle du monde), un réel dynamique simplifié, ordonné, hiérarchisé » (Bottineau, 2012: 4 - cf. II.2).

19. Umwelt fait référence au terme employé par Uexküll dans (Uexkül, J., 1909).

20. «Simplifier n'est pas simple, car cela demande d'inhiber, de sélectionner, de lier. » (Berthoz, 2009: 18).

21. in (Bottineau, 2011).

22. No specific analysis has been dealt with the syntactic arrangements appearing in minority. They could correspond to some other work of research but their structure has deliberately not been deepened in the present paper.

23. Satellite-framed languages include English, German, Dutch, Russian, Mandarin, Chinese, Finno-Ugric languages, Ojibwa, and Warlpiri. For a definition of the satellite-framed language, see I.3.

24. As defined in purely spatial terms, both verbs reveal directional, deictic values and represent motion toward the speaker (Matsumoto, 2016: 1).

25. Usage-based models refer to the "importance given to the actual use of the linguistic system and to the speaker's knowledge of this use." (Langacker, 1999: 1).

\section{RÉSUMÉS}

Le chemin linguistique a fait l'objet de nombreuses études (Talmy, 2000a ; Dan I. Slobin, 2003). La présente analyse explore un chemin sous-tendu par le phénomène du mouvement fictif (MF) : The plateau goes east along the river. Cette trajectoire, que l'on désigne 'chemin de localisation' décrit le MF d'une entité le long d'un chemin pour révéler son immobilité dans l'espace. Cet itinéraire linguistique est ici étudié à partir d'un corpus composé des verbes come et go. Si l'expérience langagière est en premier lieu vocale, elle implique aussi des procédés cinétiques non verbaux. L'expérience langagière sera alors explorée à partir des interactions qui existent entre le langage, le domaine de l'espace et le corps du sujet parlant, situant notre analyse dans une approche enactive. On définira le modèle syntaxique prototypique qui transcrit la grille d'interprétation du MF. Les structures syntaxiques récurrentes qui dévoilent la manière du locuteur de projeter son propre monde au travers de modèles simplexes seront explorées, dans le cadre de la transcription d'une réalité visuelle complexe en séquences linguistiques.

The linguistic path has been explored through several works (Talmy, 2000a; Dan I. Slobin, 2003). The present paper investigates a path underlain by the fictive motion (FM) phenomenon: The plateau goes east along the river. This itinerary, here called the 'localization path' discloses the FM of an item along a trajectory to highlight its immobility in space. This linguistic path is here inspected through a corpus-based analysis displaying the verbs come and go. If experiencing language is first vocal, this process also implies kinetic, non-verbal modalities. The languaging experience will hence be explored through the interaction between language, space and the speaker's body through an enactive approach. A prototypical syntactic configuration mirroring the interpretative grid of FM reality will be defined. Recurrent syntactic patterns revealing the way the speaker projects his own world through simplex models will highlight the way the complexity of visual scenari is converted into linguistic sequences. 
INDEX

Mots-clés : Mouvement fictif - corporéité - énaction - localisation - modèle syntaxique simplexité

Keywords : Fictive motion - embodiment - enaction - localization - syntactic pattern simplexité

\section{AUTEUR}

\section{AURÉLIE BARNABÉ}

LRL (Laboratoire de Recherche sur le Langage) - EA 999Université Clermont Auvergne (UCA) 